\title{
MINERAL DUST IN CENTRAL ASIA: 18-MONTH LIDAR MEASUREMENTS IN TAJIKISTAN DURING THE CENTRAL ASIAN DUST EXPERIMENT (CADEX)
}

\author{
Julian Hofer ${ }^{1, *}$, Dietrich Althausen ${ }^{1}$, Sabur F. Abdullaev ${ }^{2}$, Abduvosit Makhmudov ${ }^{2}$, \\ Bakhron I. Nazarov ${ }^{2}$, Georg Schettler ${ }^{3}$, K. Wadinga Fomba ${ }^{1}$, Konrad Müller ${ }^{1}$, \\ Bernd Heinold $^{1}$, Holger Baars ${ }^{1}$, Ronny Engelmann ${ }^{1}$ and Albert Ansmann ${ }^{1}$ \\ ${ }^{1}$ Leibniz Institute for Tropospheric Research (TROPOS), Leipzig, Germany, *hofer@tropos.de \\ ${ }^{2}$ Physical Technical Institute of the Academy of Sciences of Tajikistan, Dushanbe, Tajikistan \\ ${ }^{3}$ GFZ German Research Centre for Geosciences, Potsdam, Germany
}

\begin{abstract}
Tajikistan is often affected by atmospheric mineral dust. The direct and indirect radiative effects of dust play a sensitive role in the climate system in Central Asia. The Central Asian Dust Experiment (CADEX) provides first lidar measurements in Tajikistan. The autonomous multiwavelength polarization Raman lidar Polly ${ }^{\mathrm{XT}}$ was operated for 1.5 years (2015/16) in Dushanbe. In spring, lofted layers of long-range transported dust and in summer/autumn, lower laying dust from local or regional sources with large optical thicknesses occurred.
\end{abstract}

\section{INTRODUCTION}

Dust influences weather and climate on earth by direct and indirect effects. Central Asia is strongly affected by climate change which is manifested in Tajikistan in a severe glacier retreat [1]. Glacier melting rates are also influenced by dust due to the darkening of the glacier's surfaces [2]. The glaciers of Tajikistan are the major water resources of the rivers which were originally feeding the Aral Sea, which now became itself a strong dust source [3]. Therefore aerosol observations in Tajikistan are extremely valuable to understand regional and global transport of mineral dust. Only few experiments were performed to characterize the aerosol over Central Asia. During a Soviet-American campaign in 1989 two dust storms were observed [4]. During these dust, storms aerosol optical thicknesses (AOT) of up to 3.5 (at $550 \mathrm{~nm}$ ) were measured and a couple of vertical profiles of the dust distribution were measured by aircraft [5]. Dust transported from the Aral Sea region, from the Middle East and from the Taklamakan desert was reported from more recent lidar measurements conducted in Kyrgyzstan [6, 7]. Nevertheless, the knowledge of the vertical aerosol distribution over Tajikistan and especially the transport of mineral dust over Central Asia is still poor. Therefore the Central Asian Dust Experiment (CADEX) was performed to obtain long-term data on vertical profiles of optical aerosol properties.

\section{INSTRUMENTS AND METHODS}

The CADEX campaign was conducted at a field site of the Physical Technical Institute of the Academy of Sciences of Tajikistan in Dushanbe. Its coordinates are $38^{\circ} 33^{\prime} 34^{\prime \prime} \mathrm{N}$, $68^{\circ} 51$ '22" E, and its altitude is $864 \mathrm{~m}$ a.s.1..

A multiwavelength polarization Raman lidar Polly ${ }^{\mathrm{XT}}[8]$ is used for the continuous lidar measurements. All Polly ${ }^{\mathrm{XT}}$ systems emit linearly polarized light at $355 \mathrm{~nm}, 532 \mathrm{~nm}$, and $1064 \mathrm{~nm}$ wavelength generated by a Nd:YAG laser and $2^{\text {nd }}$ and $3^{\text {rd }}$ harmonic generators. Vertical profiles of the particle backscatter coefficient are determined for the three emitted wavelengths. The system measures cross-polarized light in two channels to retrieve the particle linear depolarization ratio (PLDR) at $355 \mathrm{~nm}$ and $532 \mathrm{~nm}$ wavelength. The inelastic channels at $387 \mathrm{~nm}$ 
and $607 \mathrm{~nm}$ allow to determine particle extinction coefficients at $355 \mathrm{~nm}$ and $532 \mathrm{~nm}$ with the Raman method [9] at night-time. For water vapour measurements a channel at $407 \mathrm{~nm}$ is installed. The system's vertical resolution is $7.5 \mathrm{~m}$ and the data is stored with a temporal resolution of $30 \mathrm{~s}$.

Additionally, a CIMEL sun photometer from the AERONET station in Dushanbe is collocated with the Polly ${ }^{\mathrm{XT}}$ lidar to measure the AOT and retrieve further particle properties.

The dust and non-dust mass concentrations are indirectly calculated with the polarization lidar photometer networking method (POLIPHON) $[10,11]$.

\section{RESULTS}

The Polly ${ }^{\mathrm{XT}}$ performed measurements from 17 March 2015 until 31 August 2016. During that period, data was acquired for more than 3 hours at 407 days and at 307 days even for more than 20 hours. The quicklooks of all measurements are available at http://polly.tropos.de.

During spring, numerous lofted dust layers up to $10 \mathrm{~km}$ above ground were observed. The summer months in Dushanbe are commonly dusty from the ground to certain heights with large AOT. For example, the mean AOT at $500 \mathrm{~nm}$ measured with the sun photometer (AERONET level 1.5) in August 2015 was 0.41 and in August 2016 it was 0.28.
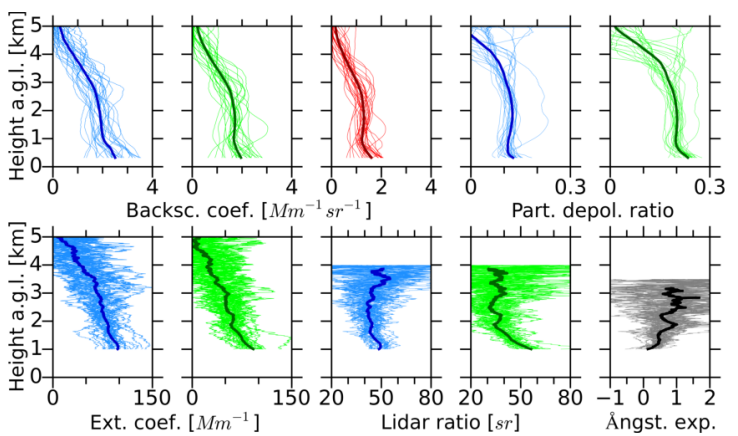

Figure 1: Vertical profiles of Raman-retrieved optical properties (with $563 \mathrm{~m}$ vertical smoothing) at each possible night $(N=28)$ during August 2016. Blue for $355 \mathrm{~nm}$, green for $532 \mathrm{~nm}$, red for $1064 \mathrm{~nm}$ wavelength, black for Angström exponent for the 355/532 nm extinction pair. The fat profiles denote the average over the respective profiles.
Figure 1 shows the optical properties measured during August 2016 at each night at which it was possible to retrieve profiles of the optical properties with the Raman method. The extinction coefficients at $355 \mathrm{~nm}$ and $532 \mathrm{~nm}$ are similar, on average decreasing from about $100 \mathrm{Mm}^{-1}$ to 0 at about $5 \mathrm{~km}$. The average lidar ratio between 1.5 and $3 \mathrm{~km}$ is $45 \pm 1 \mathrm{sr}$ at $355 \mathrm{~nm}$ and $36 \pm 3 \mathrm{sr}$ at $532 \mathrm{~nm}$. Note that these cases are not only pure dust cases, but include polluted dust and also pollution events. The PLDR values are large even on average, namely $0.12 \pm 0.01$ at $355 \mathrm{~nm}$ and $0.20 \pm 0.01$ at $532 \mathrm{~nm}$.

An outstanding profile with larger PLDR values in both wavelengths is measured on 16 August 2016 and will be discussed in detail below. The temporal development of the range corrected signal at $1064 \mathrm{~nm}$ at that day as well as the profiles of the optical properties averaged on 16 August 2016, 18:00-19:00 UTC are shown in Fig. 2.

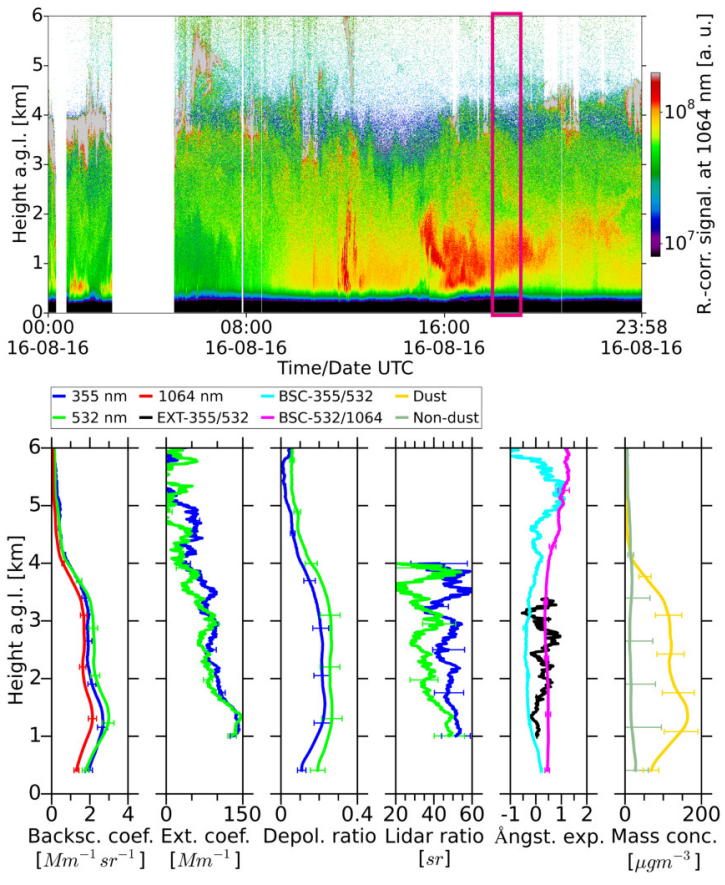

Figure 2: Top: Temporal development of the range-corrected signal at $1064 \mathrm{~nm}$ wavelength on 16 August 2016. Bottom: Averaged vertical profiles of the optical properties on 16 August 2016, 18:00-19:10 UTC (pink rectangle on the top). 
On this day, there were sporadic clouds and even some rain occurred in the morning. After 12:00 UTC and after 16:00 UTC aerosol plumes were rising up to about $2.5 \mathrm{~km}$ height. The backscatter and extinction coefficients at $532 \mathrm{~nm}$ wavelength have their maximum at $1.35 \mathrm{~km}$ height with about $3 \mathrm{Mm}^{-1} \mathrm{sr}^{-1}$ and $150 \mathrm{Mm}^{-1}$ respectively. The PLDR values are large between 1.3 and $3.5 \mathrm{~km}$ altitude and indicate dust dominated conditions. The calculated dust mass concentration reaches $164 \mu \mathrm{g} \mathrm{m}^{-3}$ and the integrated dust mass is $442 \mathrm{mg} \mathrm{m}^{-2}$.

Table 1 summarizes the averaged intensive optical properties and the AOT measured on $16 \mathrm{Au}-$ gust 2016, 18:00-19:10 UTC. The PLDR values are lower than known values for pure (Saharan) dust (0.24-0.28 at $355 \mathrm{~nm}, 0.30-0.32$ at $532 \mathrm{~nm}$ ) [12]. The values at $355 \mathrm{~nm}$ are comparable with PLDR values of transported (Saharan) dust (0.21 at $355 \mathrm{~nm})$ [13]. The measured lidar ratios are lower than for Saharan dust (35$70 \mathrm{sr}$ at $335 \mathrm{~nm}, 45-65 \mathrm{sr}$ at $532 \mathrm{~nm}$ ) [14] and comparable to Middle Eastern/West-Asian dust (34-39 sr at $532 \mathrm{~nm})$ [15].

Table 1: $S_{355}, S_{532}$ lidar ratio, $\delta_{355}^{p}, \delta_{532}^{p} P L D R$, $\tau_{\text {lidar }}$ AOT from lidar at $532 \mathrm{~nm}$ wavelength, $\tau_{S P M}$ AOT from sun photometer at $500 \mathrm{~nm}$ wavelength, $\stackrel{\circ}{3}_{355 / 532}$ extinction-related Ångström exponent.

\begin{tabular}{|l|l|}
\hline Date & 16 August 2016 \\
\hline Time [UTC] & $18: 00-19: 10$ \\
\hline Layer range $[\mathrm{km}]$ & $0.9-3.8$ \\
\hline Averaging $[\mathrm{km}]$ & $1.7-3.0$ \\
\hline$S_{355}[\mathrm{sr}]$ & $47.7 \pm 3.1$ \\
\hline$S_{532}[\mathrm{sr}]$ & $35.5 \pm 3.7$ \\
\hline$\delta_{355}^{p}$ & $0.22 \pm 0.01$ \\
\hline$\delta_{532}^{p}$ & $0.26 \pm 0.01$ \\
\hline$\tau_{\text {lidar }}$ & 0.42 \\
\hline$\tau_{S P M}(13: 08$ UTC $)$ & 0.33 \\
\hline$\alpha_{355 / 532}$ & $0.38 \pm 0.24$ \\
\hline
\end{tabular}

\section{CONCLUSIONS}

The CADEX campaign provided first long-term measurements of vertical profiles of aerosol optical properties over Tajikistan. The presented measurements from August 2016 show dusty summer conditions in the atmosphere over Tajikistan. The aerosol measured on 16 August 2016 is identified as mixed dust with a significant dust contribution.

A comparison of CADEX lidar data with chemical analysis of the aerosol at ground as well as with satellite measurements can be found in another contribution to this conference [16].

\section{ACKNOWLEDGEMENTS}

The CADEX project was funded by the German Federal Ministry of Education and Research in the context of "Partnerships for sustainable problem solving in emerging and developing countries" under the grant number 01DK14014. This project has also received funding from the European Union's Horizon 2020 research and innovation programme under grant agreement No 654109. We would like to thank the Academy of Sciences of Tajikistan, Lars Klüser from German Aerospace Center, Emmanouil Proestakis from National Observatory of Athens, Alexandra Chudnovsky from University of Tel Aviv, and Konrad Kandler from TU Darmstadt for their support.

\section{References}

[1] Kayumov, A., 2010: Glaciers Resources of Tajikistan in Condition of the Climate Change, State Agency for Hydrometeorology of Committee for Environmental Protection under the Government of the Republic of Tajikistan, https://www.wmo.int/pages/prog/www/OSY/ Meetings/GCW-IM1/glaciers.pdf.

[2] Gabbi, J., Huss, M., Bauder, A., Cao, F., Schwikowski, M., 2015: The impact of Sa- 
haran dust and black carbon on albedo and long-term mass balance of an Alpine glacier, Cryosphere, 9 (4), 1385-1400.

[3] Xi, X. and Sokolik, I. N., 2016: Quantifying the anthropogenic dust emission from agricultural land use and desiccation of the Aral Sea in Central Asia, J. of Geophys. Res. Atmos., 121 (20), 12,270-12,281.

[4] Golitsyn, G. and Gillette, D. A., 1993: Introduction: A joint Soviet-American experiment for the study of Asian desert dust and its impact on local meteorological conditions and climate, Atmos. Environ., 27 (16), 2467-2470.

[5] Pachenko, M. V., Terpugova, S. A., Bodhaine, B. A., Isakov, A. A., Sviridenkov, M. A., Sokolik, I. N., Romashova, E. V., Nazarov, B. I., Shukurov, A. K., Chistyakova, E. I., Johnson, T. C., 1993: Optical investigations of dust storms during U.S.S.R.-U.S. experiments in Tadzhikistan, 1989, Atmos. Environ., 27 (16), 2503-2508.

[6] Chen, B. B. and Sverdlik, L. G., 2007: Optical and microphysical characteristics of aerosol structures in Central Asia, International Conf. on Lasers, Applications, and Technologies 2007, 6733, 67330S

[7] Chen, B. B., Sverdlik, L. G., Imashev, S. A., Solomon, P. A., Lantz, J., Schauer, J. J., Shafer, M. M., Artamonova, M. S., Carmichael, G. R., 2013: Lidar Measurements of the Vertical Distribution of Aerosol Optical and Physical Properties over Central Asia, Int. J. Atmos. Sci., 2013, 261546.

[8] Engelmann, R., Kanitz, T., Baars, H., Heese, B., Althausen, D., Skupin, A., Wandinger, U., Komppula, M., Stachlewska, I. S., Amiridis, V., Marinou, E., Mattis, I., Linné, H., Ansmann, A., 2016: The automated multiwavelength Raman polarization and water-vapor lidar Polly ${ }^{\mathrm{XT}}$ : the neXT generation, Atmos. Meas. Tech., 9 (4), 1767-1784.

[9] Ansmann, A., Riebesell, M. A., Weitkamp, C., 1990: Measurement of atmospheric aerosol extinction profiles with a Raman lidar, Opt. Lett., 15 (13), 746-748.
[10] Ansmann, A., Seifert, P., Tesche, M., Wandinger, U., 2012: Profiling of fine and coarse particle mass: case studies of Saharan dust and Eyjafjallajökull/Grimsvötn volcanic plumes, Atmos. Chem. Phys., 12 (20), 93999415.

[11] Mamouri, R. E. and Ansmann, A., 2014: Fine and coarse dust separation with polarization lidar, Atmos. Meas. Tech., 7 (11), 3717-3735.

[12] Freudenthaler, V., Esselborn, M., Wiegner, M., Heese, B., Tesche, M., Ansmann, A., Müller, D., Althausen, D., Wirth, M., Fix, A. Ehret, G., Knippertz, P., Toledano, C., Gasteiger, J., Garhammer, M., Seefeldner, M., 2009: Depolarization ratio profiling at several wavelengths in pure Saharan dust during SAMUM 2006, Tellus B, 61 (1), 165-179.

[13] Burton, S. P., Hair, J. W., Kahnert, M., Ferrare, R. A., Hostetler, C. A., Cook, A. L., Harper, D. B., Berkoff, T. A., Seaman, S. T., Collins, J. E., Fenn, M. A., Rogers, R. R.. 2015: Observations of the spectral dependence of linear particle depolarization ratio of aerosols using NASA Langley airborne High Spectral Resolution Lidar, Atmos. Chem. Phys., 15 (23), 13453-13473.

[14] Tesche, M., Ansmann, A., Müller, D., Althausen, D., Mattis, I., Heese, B., Freudenthaler, V., Wiegner, M., Esselborn, M., Pisani, G., Knippertz, P., 2009: Vertical profiling of HSRL in southern Morocco during SAMUM, Tellus B, 61 (1), 144-164.

[15] Mamouri, R. E., Ansmann, A., Nisantzi, A., Kokkalis, P., Schwarz, A., Hadjimitsis, D. G., 2013: Low Arabian dust extinction-tobackscatter ratio. Geophys. Res. Lett., 40 (17), 4762-4766.

[16] Althausen, D., Hofer, J., Abdullaev, S. F., Makhmudov, A., Baars, H., Engelmann, R., Fomba, K. W., Müller, K., Schettler, G., Klüser, L., Kandler, K.,: 2017: Combining lidar and other measurements during the Central Asian Dust Experiment (CADEX), Proceedings of the $28^{\text {th }}$ IRLC, Bucharest. 